Acta Orientalia Academiae Scientiarum Hung. Volume 54 (2-3), 187-189 (2001)

\title{
NEW LIGHT ON THE VERSE 112 OF THE KRSIPARĀŚARA
}

\author{
GYULA WOJTILLA* \\ (Budapest)
}

\begin{abstract}
The description of the plough in the Krșiparāsara has been a puzzle for generations of Sanskrit philologists. What especially pained me was the disfunctional character of this description: among the eight essential parts the ploughshare was missing. The turning up of an until now unknown manuscript from The Library of Congress has brought a basic change: it contains the expected reading phālikā "ploughshare" for pāśikā an otherwise meaningful term "rope" that could have been adjusted to the context only by rather strained explanations. a solution.

The present paper throws light on the problems concerned in the textual tradition and offers
\end{abstract}

Key words: Krșiparāśara, pāśikā, phālikā, paccan̄̄, prājanī, plough, ploughshare, goad, The Library of Congress, Eugene Hotaling.

The special vocabulary of the Krșiparāśara (KP), a treatise upon agriculture, has attracted the attention of philologists and lexicographers since its first publication in 1862. After the appearance of the critical edition and a reliable English translation (Majumdar-Banerji 1960) the number of enigmatic terms became a great deal less. Nevertheless the highly important passages bearing on the parts of plough remained problematic. It is mainly due to the presence of deś $\bar{\imath}$ words and the loose redaction of the work itself. No wonder that the learned brāhmana Daśarathaśāstri who almost entirely incorporated the KP in his Krșiśäsana omitted these passages and replaced them with the description of the Brhatparäśarasamhitā (Wojtilla 1993, p. 528). On the basis of this critical edition and one manuscript kept at the British Library (Ms Tagore 24. Cat. No. 6475) that was not taken into consideration by the editors I was able to interpret almost all of the terms in question (Wojtilla 1977). This interpretation is coherent as far as the readings of the critical edition and the above-mentioned manuscript go, however, the picture that emerged from the enumeration of the constituent parts of the plough seemed to me defective. I did not keep silent about my doubts saying that the enumeration of the eight parts by the author is ill-considered:

${ }^{*}$ Gyula Wojtilla, Department of Ancient History, University of Szeged, H-6722 Szeged, Egyetem u. 2. Hungary, e-mail: wojtilla@antiq.u-szeged.hu 
an essential part, namely the ploughshare, was missing from this list (Wojtilla 1977, p. 251). What is strange, nobody before me and after me was baffled by this problem! I accepted the translation of the the term passika in the sense proposed by Majumdar and Banerji who took over that of MW "a strap of leather on the plough" (MW, p. 623) and that of Ganguli "iron plates that fix the share to the niryola" (Ganguli 1932, p. 74) and also referred to the variant reading pălika "maintainer" (Banerji 1955 , p. 17) with a remark that this form also does not lead us nearer to an apt solution (Wojtilla 1977, pp. 247-248). In the following years I succeeded to procure a copy of the editio princeps of KP (TThākura 1862) which was not used by Majumdar and Banerji in constituting their text (cf. Gopal 1973, p. 151, n. 4). It is a pity that this edition also relies on that Calcutta manuscript which served as a basis of all used by Majumdar and Banerji. Consequently it gives the same reading. In a second study where I compared the data of KP with that of other texts I could but come out with my own interpretation saying that the term passika means "a rope that ties the shaft/handle to the head/plough bottom" (Wojtilla 1988, p. 330). It was more convincing than the translation offered by MW or Ganguli or even the rendering by Choudhary "a small piece of wood fitted on the top of the plough handle for an easy grasp" (Choudhary 1971, p. 151). The latest interpretations are the "rope of niryola" (Chowdhury 1992, p. 40) and taking niryolapāsika one word "handle" (Sadhale 1999, p. 55).

Research appeared to reach a deadlock and then unexpectedly a hitherto unknown manuscript turned up, a copy of which was sent me by Professor R. P. Das with the permisson of A. W. Thrasher, senior reference librarian, Asian Division, The Library of Congress, Washington. The manuscript was deposited at The Library of Congress by the late Eugene Hotaling, former professor of education at Valley City State College in North Dakota. Its script is Bengali, the number of folios is 8 , that is 16 pages, and there are 9 lines on each page. It bears the title Krssipaddhati like the R. 15. 87 manuscript in Bengali script at the Library of Trinity College, Cambridge which dates from the end of the eighteenth century (Aufrecht 1869, pp. 25-27) and the manuscript 1274 (H. T. Colebrooke, Catalogue No. 3168) in Bengali characters of the British Library (Majumdar-Banerji 1960, Text p. iv). A pilot study on its contents revealed to me that the manuscript preserved a text that contains significant variant passages in comparison with the other manuscripts and the text constituted in the critical edition. What is revealing is its reading of the verse 112 where phālikā "ploughshare" stands for $p \overline{a s} i k a \bar{l}$ ! Similarly, it is noteworthy that the manuscript reads prājan̄ for paccan̄̄ accepted by Majumdar and Banerji. As a matter of fact prājani (with short -i-) is the common word for "goad" in classical Sanskrit (Wojtilla 1988, p. 338). Kuiper took paccani as the Sanskritised form of pācani and regarded it as the strongest evidence for a Bengali provenance of the work (Kuiper 1969, p. 215). I think that without the reconstruction of the whole manuscript tradition of KP it cannot be decided whether it is the older reading or not. After this the verse can be constituted tentatively thus: īṣāyugahalasthānuniryolastasya phālikā $\mid$ addacallaśca śaulaśca paccanī ca halāsțakam, i.e. "pole, yoke, a strong piece of wood that is fixed to the niryola which is held by the cultivator while ploughing (halasthānu), shaft 
(niryola) and its ploughshare (phälikāa) | the inner pin of the yoke (addacalla) an extra piece of wood that tightly fixes the niryola to the pole (or less probably: the outer pin of the yoke) (śaula) and goad - (these are) the eight parts of the plough".

This fatal error that has misled scholars since 1862 can be due to the ignorance of the scribes who had not even a touch of practical common sense and put there $p \bar{a} l i k \bar{a}$ or even pulikā without hesitation. It is an open question whether Thākura had used a manuscript where the form $p \bar{a}$ sik $\bar{a}$ stood or he emended any other one he had found wrong. Majumdar and Banerji seem to rely on the reading presented by the Vangavāsī edition (Kāvyatīrtha 1915) which took over the reading from the editio princeps. This is why Majumdar and Banerji did not feel the need to put the former one on the list of text consulted. On the other hand the reading of the Library of Congress manuscript must be looked upon as genuine and cannot be attributed to a later emendation. It is curious that in the last hundred and forty years nobody dared to make a conjectural emendation. The great value of the discovery of this manuscript for international scholarship lies in its originality.

\section{References}

Aufrecht, Th. (1869): A Catalogue of Sanskrit Manuscripts of the Library of Trinity College, Cambridge. Cambridge.

Choudhary, A. K. (1971): Early Medieval Village in North-eastern India. (A. D. 600-1200). Calcutta, Punthi Pustak.

Chowdhury, K. A. (1992): Krși-Parāśara. Indian Journal of History of Science. Vol. 27, No. 1. pp. 31-49.

Ganguli, R. C. (1932): Some Materials for the Study of Agriculture and Agriculturists in Ancient India. Serampore, Baptist Press.

Gopal, L. (1973): The Date of the Kṛ̣i-Parāśara. Journal of the Indian History, Vol. 50, pp. 151168.

Kāvytīrtha 1915 = Krṣi-Samgraha. Ed. Tārākānta Kāvyatīrtha with Bengali translation. Calcutta 1322 B. S. [1915], pp. 1-52.

Kuiper, F. B. J. (1969): Review on Majumdar-Banerji 1960. IIJ, Vol. 21, No. 2, pp. 213-215.

Majumdar, G. P.-Banerji, S. C. (eds) (1960): Kṛsi-Parāśara. Translated by the editors. Calcutta, The Asiatic Society.

MW = Monier-Williams, M. (1960): A Sanskrit-English Dictionary. Oxford, Clarendon Press.

Sadhale, N. (1999): Krishi-parashara (Agriculture by Parashara). Translated by N. Sadhale. Secunderabad. Asian Agri-History Foundation.

Ṭhākura, P. (ed.) (1862): Kṛsisangraha. Kālikātā.

Wojtilla, Gy. (1977): The Plough as Described in the Krșiparāśara. AOF, Vol. 5, pp. 245-252.

Wojtilla, Gy. (1988): The Sanskrit Terminology of the Plough. AOH, Vol. 42. Nos 2-3, pp. 325338.

Wojtilla, Gy. (1993): Notes on Daśarathaśāstrin's Kṛșiśāsana. Annals of the Bhandarkar Oriental Research Institute, Vols 72-73, pp. 527-532. 